\title{
Neuropeptides as Attractants of Immune Cells in the Brain and their Distinct Signaling
}

\author{
Mami Noda*, Masataka Ifuku, Yuko Okuno, Kaoru Beppu, Yuki Mori and Satoko Naoe \\ Laboratory of Pathophysiology, Graduate School of Pharmaceutical Sciences, Kyushu University, Fukuoka, Japan
}

\begin{abstract}
Microglia, the immune cells of the central nervous system (CNS), are busy and vigilant housekeepers in the adult brain. The main candidate as a chemoattractant for microglia at damaged site is adenosine triphosphate (ATP). However, many other substances can induce immediate change of microglia. Some neuropeptides such as angiotensin II, bradykinin (BK), endothelin, galanin (GAL), and neurotensin are also chemoattractants for microglia. Among them, BK increased microglial migration via $\mathrm{B}_{1}$ receptor with different mechanism from that of ATP. BK-induced migration was controlled by a $\mathrm{G}_{\mathrm{i} / \mathrm{o}}$ protein-independent pathway, while ATP-induced migration was via a $\mathrm{G}_{\mathrm{i} / \mathrm{o}}$ protein-dependent and also a mitogen-activated protein kinase (MAPK) / extracellular signal-regulated kinase (ERK)-dependent pathway. On the other hand, GAL is reported to have a similar signal cascade as that of BK, though only part of the signaling was similar to that of BK-induced migration. For example, BK activates reverse-mode $\mathrm{Na}^{+} / \mathrm{Ca}^{2+}$ exchange allowing extracllular $\mathrm{Ca}^{2+}$ influx, while GAL induces intracellular $\mathrm{Ca}^{2+}$ mobilization via increasing inositol-1,4,5-trisphosphate. In addition, GAL activates MAPK/ERK-dependent signaling but BK did not. These results suggest that chemoattractants for immune cells in the brain including ATP and each peptide may have distinct role under both physiological and pathophysiological conditions.
\end{abstract}

Keywords: Microglia, migration, ATP, neuropeptides, $\mathrm{Ca}^{2+}$-dependent $\mathrm{K}^{+}$channels, $\mathrm{Na}^{+} / \mathrm{Ca}^{2+}$ exchange mechanism, $\mathrm{IP}_{3}$

\section{INTRODUCTION}

In the brain, glial cells are considered to be the pathologic response element; both microglial cells [1-3] and astrocytes (see review [4]) are involved in pathologic events. Microglial cells represent the immune system of the mammalian brain and therefore are critically involved in various injuries and diseases. On the other hand, astrocytes are the most abundant non-neuronal cells in the central nervous system (CNS), and their role in physiological and pathophysiological processes is becoming increasingly appreciated [5].

Microglial migration plays a central role in immune defense and wound healing. Microglial cells exhibit

\footnotetext{
${ }^{*}$ Correspondence to: Mami Noda, Ph.D., Laboratory of Pathophysiology, Graduate School of Pharmaceutical Sciences, Kyushu University, Fukuoka 812-8582, Japan. 3-1-1 Maidashi, Higashiku, Fukuoka 812-8582, Japan. Tel./Fax: +81 92642 6574; E-mail: noda@phar.kyushu-u.ac.jp.
}

two types of movement activity: in the ramified form, they actively move their processes without translocation of the cell body. In the amoeboid form, they also move their processes, but in addition the entire cell can migrate within brain tissue including translocation of their soma. It is not yet explored whether these forms of motility, migration and process movement are distinctly regulated. Nevertheless, there are many candidate molecules which serve as signals for pathologic events to microglia including ATP $[6,7]$, cannabinoids [8], morphine [9], the chemokine CCL21 [10], lysophosphatidic acid [11], neurotransmitters such as glutamate [12], dopamine and adrenaline [13], and bradykinin (BK) [14] (Fig. 1). In addition, ion channels and transporters play an important role in cell migration such as $\mathrm{K}^{+}$channels, $\mathrm{Cl}^{-}$channels, $\mathrm{Na}^{+} / \mathrm{H}^{+}$exchanger, $\mathrm{Cl}^{-} / \mathrm{HCO}_{3}{ }^{-}$exchanger, and $\mathrm{Na}^{+} / \mathrm{HCO}_{3}{ }^{-}$cotransporter, all of which are linked to the actin cytoskeleton $[15,16]$.

Microglial cells express quite different types of receptors. Beside Toll-like receptors, they express 


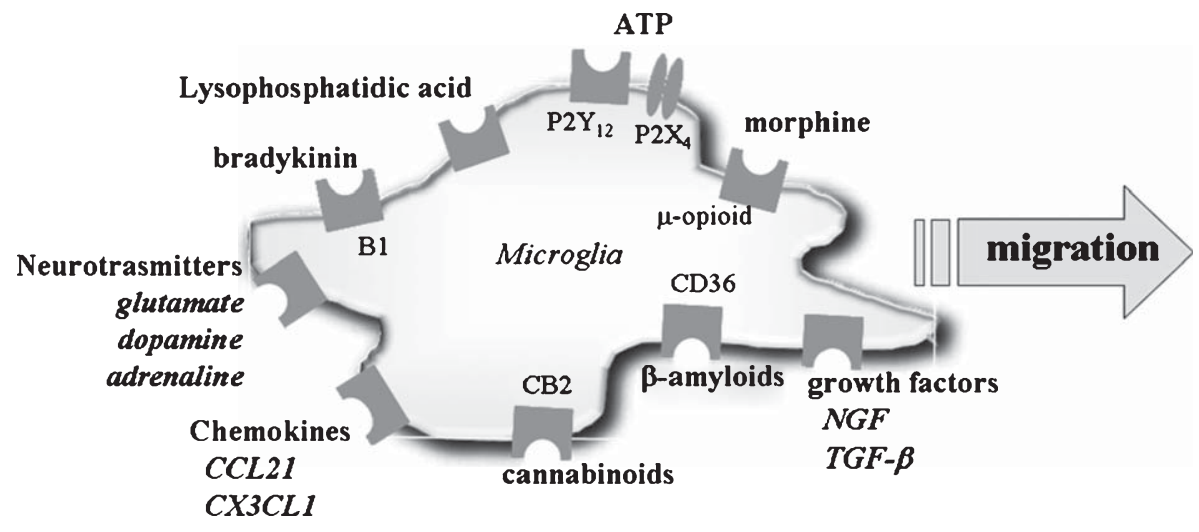

Fig. 1. Microglial migration is induced by various substances and activation of their receptors. There are many candidate molecules which serve as signals for pathologic events to microglia including ATP, cannabinoids, morphine, chemokines, lysophosphatidic acid, neurotransmitters such as glutamate, dopamine and adrenaline, and BK. In addition, ion channels and transporters play an important role in cell migration such as $K^{+}$ channels, $\mathrm{Cl}^{-}$channels, $\mathrm{Na}^{+} / \mathrm{H}^{+}$exchanger, $\mathrm{Cl}^{-} / \mathrm{HCO}_{3}{ }^{-}$exchanger, and $\mathrm{Na}^{+} / \mathrm{HCO}_{3}{ }^{-}$cotransporter (not shown). It is probable that there will be more candidates, such as neuropeptides, to serve as signals for pathologic events to microglia and regulate their migration.

receptors for neurotransmitters, neuropeptides, hormones, and cytokines. In the last century, many neuropeptides and hormonal peptides were identified. They are involved in wide variety of physiological and pathophysiological functions such as eating and sleeping, pain and inflammation. Recent findings also support a major role for neuropeptides in mediating the responses to stress and thereby identify the neuropeptide system as potential novel therapeutic targets for the treatment of depression and anxiety disorders $[17,18]$. Neuropeptides are short-chain amino acid neurotransmitters and neuromodulators, often localized in brain regions that mediate emotional behaviors and the response to stress [19]. Though many receptors and their signaling in glial cells are in common with neuronal ones, their functions are quite different between neurons and glial cells, and the functional role of neuropeptides in glial cells are not well known.

Among neuropeptides or peptides in the CNS, kinins including BK are a family of endogenous peptides, which participate in several pathophysiological events. They are formed in plasma and tissues via the kallikrein-kinin system in response to infection, tissue trauma or inflammatory reactions, such as increase in vascular permeability, oedema formation and pain. Among kinins, BK is widely distributed not only in the periphery but also in the brain [20-23]. Although BK is frequently regarded as an inflammatory mediator in the brain, we showed that it does not appreciably induces inflammatory cytokines in microglia but instead suppresses the release of inflammatory cytokines (e.g. TFN- $\alpha$ and IL-1 $\beta$ ) from microglia induced by bacterial lipopolysaccharide (LPS), and that this could mediate an anti-inflammatory (neuroprotective) effect on the CNS [24, 25]. The neuroprotective role of BK against glutamate toxicity was also reported in the retina [26]. In support of this idea, it was reported that BK receptor antagonists increased mortality in an animal model of global cerebral ischemia; hence the therapeutic effect of specific BK receptor antagonists on functional outcome remains unclear [27]. Recent observation also showed that $\mathrm{B}_{1} \mathrm{BK}$-receptor is protective for $\mathrm{T}$ cell recruitment in autoimmune encephalomyelitis (EAE) [28].

BK receptors have been identified in microglia [29] and astrocytes [30-33]. In astrocytes, BK induced expression of matrix metalloproteinase-9, phospholipase $A_{2}$ and COX-2 [34-36] and increased expression and secretion of IL-6 [37] and glutamate [38]. Taken together, BK has multiple effects on different types of cells, inducing both inflammatory and antiinflammatory cascades.

In the previous studies, we provided evidence that $\mathrm{BK}$ receptors in microglia mediate anti-inflammatory or neuroprotective effects, namely the inhibition of LPS-induced release of TNF- $\alpha$ and IL-1 $\beta$ [25]. It was also reported that $\mathrm{BK}$ reduced $\mathrm{A} \beta$-induced expression of proinflammatory genes including iNOS and COX2 , playing an important role in $A \beta$ clearance [39]. In the brain, microglial cells are dispersed throughout the entire CNS and exhibit a ramified morphology under normal conditions, but their processes are highly dynamic [7, 40], respond to mechanical stimuli or to focal application of ATP, suggesting that microglial 
cells scan the brain parenchyma and potentially shield it from injury. Their processes move rapidly toward a site of injury, for example a damaged blood vessel in the brain, in response to the localized release of a chemoattractant such as ATP. According to these observations, microglial cells quickly extend their processes and form a barrier to protect healthy tissue [41].

BK levels are also up-regulated at the site of injury and can be a candidate as one of the chemoattractants released from injured sites. In fact, BK increased the motility of microglia and attracted them, as revealed by using Boyden chamber [14]. In many pathological conditions, microglial cells are activated and have been reported to release immunoregulatory molecules such as cytokines or chemokines, and other substances including growth factors, such as growth factors [42], $\mathrm{PGE}_{2}$ and NO [43-45]. However, these substances are not always toxic but are sometimes neurotrophic, depending on the circumstances and their concentrations. This is why the role of microglia is called a double-edged sword. The problem is that little is known about the role of microglia in the healthy brain and their immediate reaction to brain damage. It has been shown that blood-brain barrier disruption provoked immediate and focal activation of microglia, switching their behavior from patrolling to shielding of the injured site. Microglia are thus busy and vigilant housekeepers in the adult brain [40]. Though the main candidate as a chemoattractant for microglia at damaged site was ATP [7], many other substances can also induce immediate change of microglia. Furthermore, previous studies showed that extracellular ATP can induce ATP release from astrocytes. ATP also mediates communication between astrocytes and between astrocytes and microglia. Likewise, other substances released from neurons, blood vessels, astrocytes, or microglia may have multiple effects on different cell types and communicate each other.

Here we show the effects of various neuropeptides on microglial migration and then summarize different mechanisms of neuropeptides, such as BK and galanin (GAL), from those of ATP, the most prominent chemoattractant of microglia. Furthermore, it is pointed out that even neuropeptides which are reported to have similar intracellular signaling have different signal cascade to increase intracellular $\mathrm{Ca}^{2+}$, which leads to cell migration. This information may help to understand the role of ATP and individual neuropeptides in the brain's immune cells and how they contribute to neuronal activity under physiological and pathophysiological conditions.

\section{EFFECTS OF VARIOUS NEUROPEPTIDES ON MICROGLIAL MIGRATION}

Microglial cells isolated from mixed cultures of cerebrocortical cells of Wistar rats were used in postnatal day 3 as described previously [29]. The motility of microglia under controlled temperature $\left(37^{\circ} \mathrm{C}\right)$ and gas $\left(10 \% \mathrm{CO}_{2} / 90 \%\right.$ air $)$ was monitored with a time-lapse video microscopy system. The average distance of microglial migration within $1 \mathrm{~h}$ was measured in the presence of various neuropeptides as follows; angiotensin-II; $100 \mathrm{nM}(n=17), \mathrm{BK} ; 300 \mathrm{nM}$ $(n=15)$, bombesin; $1 \mathrm{nM}(n=26)$, endotheline 1 (ET$1) ; 100 \mathrm{nM}(n=16), \mathrm{GAL} ; 0.1 \mathrm{pM}(n=20)$, neurotensin (NT); $10 \mathrm{nM}(n=17)$, oxytocin; $1 \mathrm{nM}(n=24)$, somatostatin; $10 \mathrm{nM}(n=20)$, substance $\mathrm{P}(\mathrm{SP}) ; 1 \mathrm{nM}(n=25)$, thyrotropin releasing hormone (TRH); $1 \mu \mathrm{M}(n=10)$, vasopressin; $1 \mathrm{nM}(n=20)$, and vasoactive intestinal peptide (VIP); $10 \mathrm{nM}(n=23)$. The concentration of each neuropeptide was chosen as a typical concentration for biological assays in previous studies. As shown in Fig. 2, angiotensin-II, BK, ET-1, GAL, and neurotensin induced significant increase in microglial motility.

\section{DIFFERENT MECHANISMS \\ OF MICROGLIAL MIGRATION INDUCED BY BK AND ATP}

Microglial migration induced by $\mathrm{BK}$ and that induced by ATP are caused by different mechanisms.

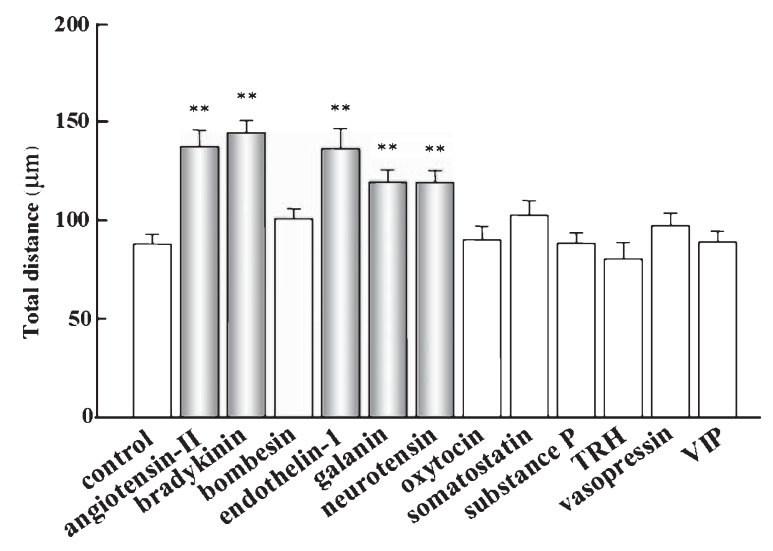

Fig. 2. Effects of various neuropeptides on microglial motility. Total distance shows the average distance of microglial migration within $1 \mathrm{~h}$. Angiotensin-II (100 nM), BK (300 nM), ET-1 (100 nM), GAL $(0.1 \mathrm{pM})$, and neurotensin $(10 \mathrm{nM})$ showed significant increase in microglial motility compared to that in the absence of neuropeptides with vehicle (control). ** $p<0.005 "$. 
BK-induced migration and lysophosphatidic acid (LPA)-induced migration (not shown) were Pertussis toxin (PTX)-resistant and therefore controlled by a

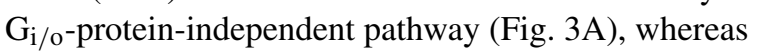

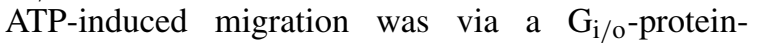
dependent pathway [6] (Fig. 3B). Cell migration needs an intracellular $\mathrm{Ca}^{2+}$ rise. Application of ATP $(100 \mu \mathrm{M})$ induced $\mathrm{Ca}^{2+}$ signals (due to the activation of both $\mathrm{P} 2 \mathrm{Y}$ and $\mathrm{P} 2 \mathrm{X}$ receptors [46-48]), with a larger amplitude than BK $[29,49]$. ATP evoked an increase of $\left[\mathrm{Ca}^{2+}\right]_{i}$ even in cells which did not respond to BK, suggesting that the majority of cultured microglial cells possess ATP receptors but not functional BK receptors.

As for the mechanism of intracellular $\mathrm{Ca}^{2+}$ rise, $\mathrm{BK}$ induces $\mathrm{Ca}^{2+}$ influx due to the activation of reverse mode of $\mathrm{Na}^{+}-\mathrm{Ca}^{2+}$ exchanger 1 (NCX1). BK-, but not ATP-induced microglial migration was attenuated in microglia from transgenic mice expressing lower NCX1 (NCX1 $1^{+/-}$mice) (Fig. 3C). Since knock-out of $\mathrm{NCX} 1$ genes $\left(\mathrm{NCX}^{-/-}\right)$is lethal, it was not possible to use NCX1 double knock-out mice. Operational $\mathrm{Na}^{+}$-dependent $\mathrm{Ca}^{2+}$ uptake was already detected in cultured microglial cells in 2001 [50]. Subsequent experiments revealed an expression of all three NCX isoforms, NCX1, NCX2 and NCX3, at both translational and protein levels in cultured rat microglia [51]. At the mRNA level expression of NCX1 was dominant, and was larger than in neurons from the same animals; expression of NCX2 and NCX3 was weak, being much less than in nerve cells [51]. As for the mechanism whereby ATP induces intracellular $\mathrm{Ca}^{2+}$ rise, ionotropic ATP receptors such as P2X4 and $\mathrm{P} 2 \mathrm{X} 7$ would presumably contribute to the influx of $\mathrm{Ca}^{2+}$. Actually, the specific importance of P2X4 receptors in ATP-induced migration has been reported [52].

As a consequence of the intracellular $\mathrm{Ca}^{2+}$ rise, $\mathrm{Ca}^{2+}$-dependent $K+\left(\mathrm{K}_{(\mathrm{Ca})}\right)$ channels are activated. It
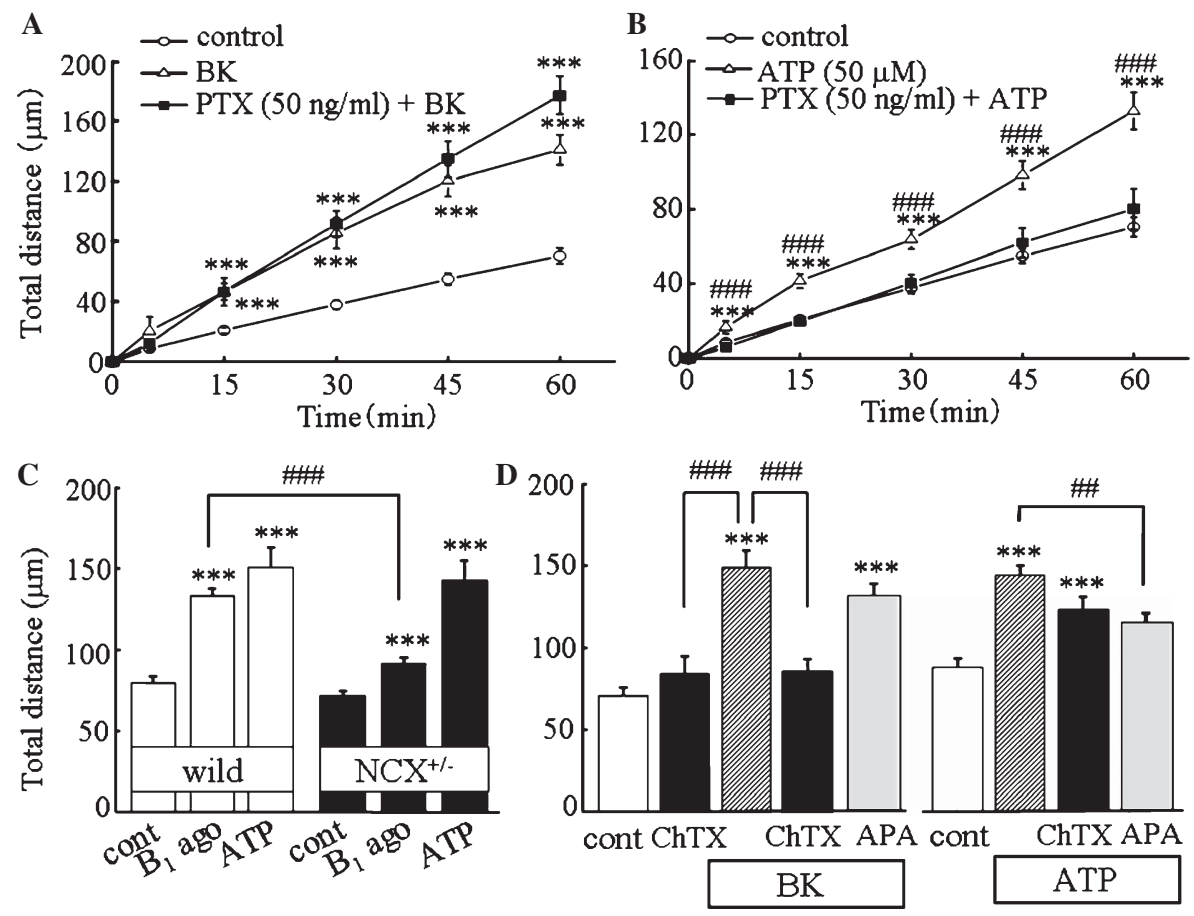

Fig. 3. Different signaling in BK- and ATP-induced microglial migration. A, Total distance (in micrometers) of microglial migration for $1 \mathrm{~h}$ of microglial cells was increased by BK $(300 \mathrm{nM})$. PTX did not affect BK-induced microglial motility $(n=20)$. $* * * p<0.001$. B, Pretreatment of PTX $(50 \mathrm{ng} / \mathrm{ml}$ ) for $12 \mathrm{~h}$ (with additional $50 \mathrm{ng} / \mathrm{ml}$ PTX before application of ATP) almost completely blocked the effect of ATP. $* * * p<0.001$, significantly different from control. \#\#\#p $<0.001$, significantly different from ATP + PTX. C, B 1 agonist (Des-Arg ${ }^{9}$-BK)-induced microglial motility in wild-type $\left(\mathrm{NCX}^{+/+}\right)$mice (open bar) and $\mathrm{NCX}$ knock-out $\left(\mathrm{NCX}^{+/-}\right)$mice (filled bar). In wild-type mice, $300 \mathrm{nM}$ Des-Arg ${ }^{9}$-BK induced microglial motility was 1.7 -fold increased, whereas in $\mathrm{NCX}^{+/}$- mice, Des-Arg 9 -BK-induced microglial motility was only 1.3 -fold increased. D, Charibdotoxin (ChTX, $0.1 \mu \mathrm{M})$, an inhibitor of LK-type (large-conductance) and IK-type (intermediate-conductance) of $\mathrm{K}_{(\mathrm{Ca})}$ channels, blocked BK-induced microglial motility, but apamin (APA), a SK-type (small-conductance) $\mathrm{K}_{(\mathrm{Ca})}$ channel blocker, had no effect on BK-induced microglial motility. E. ATP $(50 \mu \mathrm{M})$-induced microglial motility was not affected by ChTX $(0.1 \mu \mathrm{M})$, but was inhibited by APA. $* * *<0.001 ; \# \# p<0.005$, \#\#\#p<0.001. 
has been reported that charybdotoxin-sensitive $\mathrm{K}_{(\mathrm{Ca})}$ channels were important in the migration of various cell types such as leukocytes and fibroblasts $[15,16]$, though there was no information which type of $\mathrm{K}_{(\mathrm{Ca})}$ channel is important in each cell type. BK-induced migration of microglia was dependent on activation of charybdotoxin $(\mathrm{ChTX})$-sensitive $\mathrm{K}_{(\mathrm{Ca})}$ channels. Since iberiotoxin (IBX) and apamin (APA) (blockers of LK-type (large conductance) and SK-type (small conductance) $K_{(C a)}$ channels, respectively) had no effect on BK-induced microglial motility [14] (Fig. 3D), it is most likely that IK-type (intermediate conductance) $\mathrm{K}_{(\mathrm{Ca})}$ channels play an important role in BK-induced migration. On the other hand, ATP-induced microglial migration was not inhibited by ChTX but significantly inhibited by APA (Fig. 3D), suggesting that ATPinduced microglial migration was dependent on the activation of SK-type $\mathrm{K}_{(\mathrm{Ca})}$ channels.

Additional difference in signal cascade between BK and ATP was that ATP-induced microglial migration was dependent on MAPK/ERK pathway but BKinduced microglial migration was not. PD98059, a mitogen-activated protein (MAP) kinase/extracellular signal-regulated kinase (ERK) inhibitor, did not affect BK-induced microglial migration. On the other hand, ATP-induced migration was significantly inhibited by pretreatment with PD98059 (Fig. 4).

A
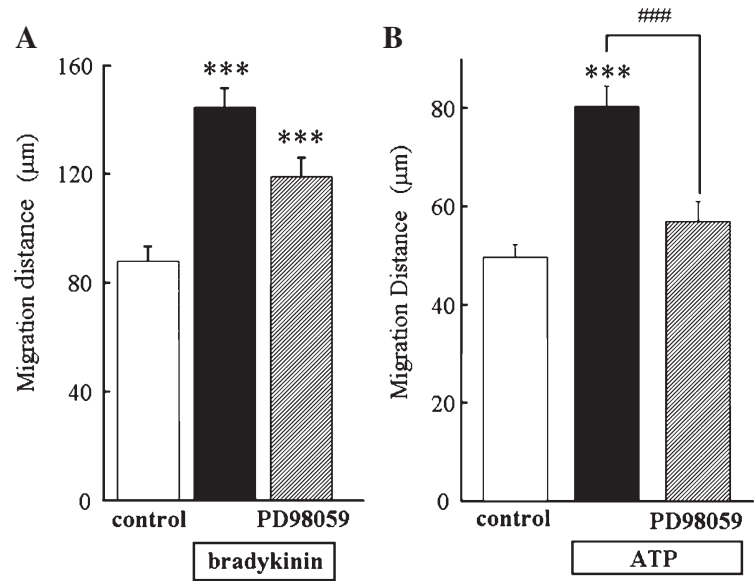

Fig. 4. Difference in MAP/ERK-dependence between BK- and ATP-induced microglial migration. A. BK-induced microglial motility was not affected by pretreatment of MAP/ERK inhibitor, PD98059 $(10 \mu \mathrm{M}), 24 \mathrm{~h}$. B. On the contrary, ATP-induced microglial motility was significantly inhibited by pretreatment of PD98059 $(10 \mu \mathrm{M}), 24 \mathrm{~h}$. $* * * p<0.001$, and ${ }^{\# \# \#} p<0.001$.

\section{DIFFERENT MECHANISMS \\ OF MICROGLIAL MIGRATION INDUCED BY BK AND GAL}

GAL is the 29 amino acid peptide, named after the $\mathrm{N}$-terminal glycine and $\mathrm{C}$-terminal alanine, and was first isolated from porcine intestinal extracts [53]. GAL is widely, but not ubiquitously, expressed in the adult nervous system. The expression of GAL is markedly up-regulated in many neuronal tissues after nerve injury or disease [54-56]. The physiological effects of GAL are mediated by the activation of one or more of the three known G protein-coupled GAL receptor subtypes designated GalR1, GalR2 and GalR3 [57]. GAL receptor subtypes are distributed widely throughout the brain, spinal cord, and peripheral nervous system [58-60]. Among them, GalR2 showed robust expression in rat brain and is also expressed in rat cultured microglia [61]. All three receptors couple to $G_{i / o}$ and inhibit adenylyl cyclase $[62,63]$ but GalR2 can also signal via $\mathrm{G}_{\mathrm{q} / 11}$ to activate phospholipase $\mathrm{C}$ (PLC) and protein kinase $\mathrm{C}$ (PKC) [64, 65], which is similar to the signaling pathway induced by BK.

GAL-induced microglial migration was also PTXresistant and therefore controlled by a $\mathrm{G}_{\mathrm{i} / \mathrm{o}}$-proteinindependent, presumably $\mathrm{G}_{\mathrm{q} / 11}$-protein dependent pathway [66]. In our previous study, BK-induced microglial migration was dependent on extracellular $\mathrm{Ca}^{2+}$ and was inhibited by chelating extracellular $\mathrm{Ca}^{2+}$ by BAPTA-AM, a membrane-permeable form of $\mathrm{Ca}^{2+}$ chelator BAPTA (1,2-bis(o-aminophenoxy) ethane-N,N, $\mathrm{N}^{\prime}, \mathrm{N}^{\prime}$-tetraacetic acid) (Fig. 5A). On the other hand, GAL-induced microglial migration induced by a galanin-like peptide (GALP), a more specific agonist for GALR2 which is the main GAL receptor in microglia, was affected by BAPTA-AM but not by deleting extracellular $\mathrm{Ca}^{2+}$ (Fig. 5B). Judged by the effect of an NCX inhibitor (Fig. 5C), the reverse mode of NCX1 was important in BKinduced microglial migration, inducing an influx of extracellular $\mathrm{Ca}^{2+}$ [14]. However, the specific NCX inhibitor, SN-6, did not block the effect of GALP (Fig. 5D). Instead, the classical $\mathrm{G}_{\mathrm{q} / 11}$ pathway leading to $\mathrm{IP}_{3}$-induced intracellular $\mathrm{Ca}^{2+}$ mobilization, and activation of PKC were involved in GALinduced migration [66]. MAPK/ERK pathway was also involved in GAL-induced microglial migration, as in ATP-induced migration [66].

An additional difference between BK and GAL is that BK induced iNOS expression [49] whereas GAL did not [66]. It was suggested that $\mathrm{BK}$, produced at the site of injury or inflammation, produces NO to dilate 

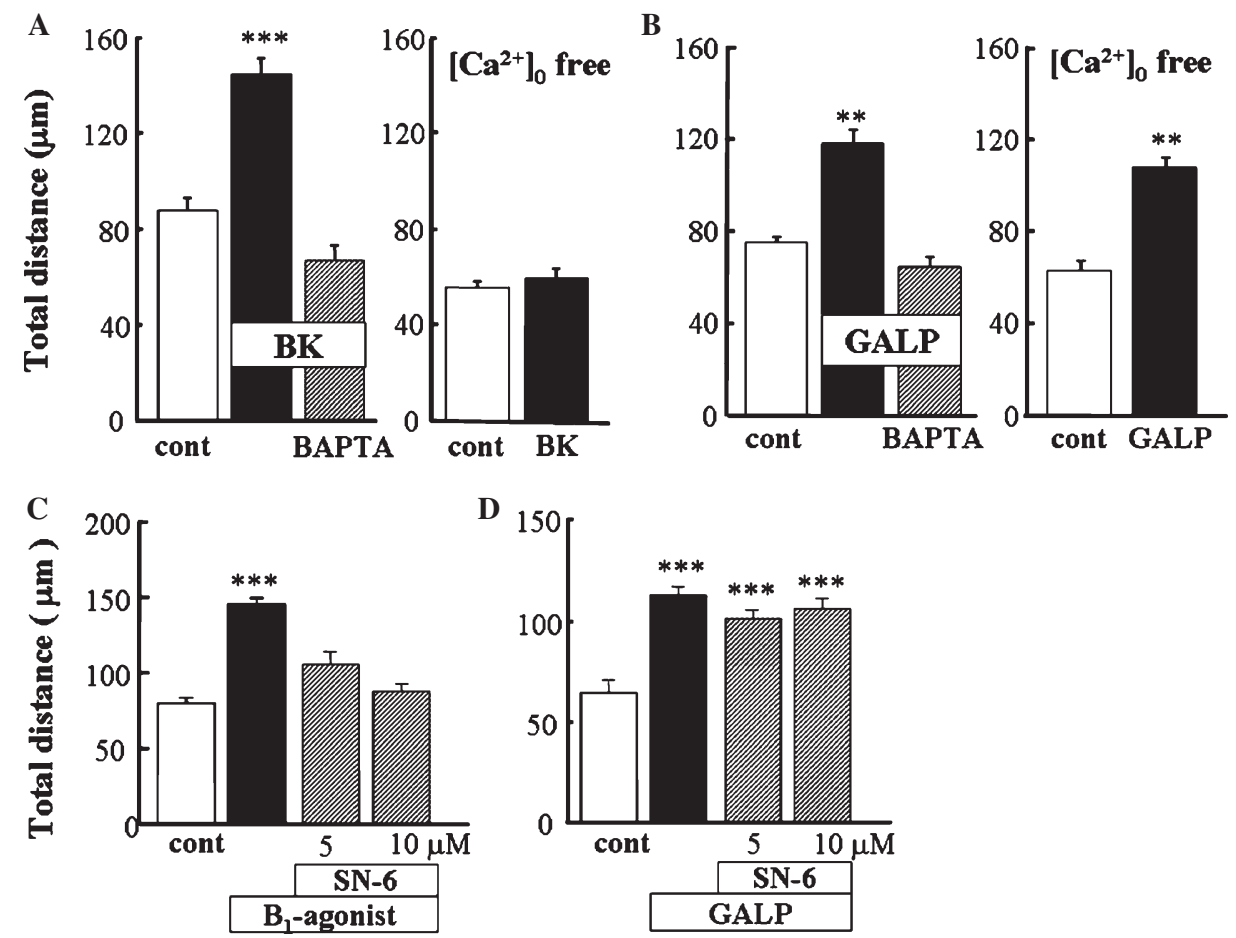

Fig. 5. Difference in extracellular $\mathrm{Ca}^{2+}$-dependence in BK-and GALP-induced migration. A, Microglial motility in the presence of BK was significantly inhibited by pretreatment with BAPTA-AM $(10 \mu \mathrm{M})$ for $20 \mathrm{~min}$. In the absence of extracellular $\mathrm{Ca}^{2+}\left(\left[\mathrm{Ca}^{2+}\right]_{0}\right.$ free $)$, total distance (in micrometers) of microglial migration was not increased by BK $(300 \mathrm{nM})(n=19)$. B, Microglial motility in the presence of GALP (500 pM) was significantly inhibited by pretreatment with BAPTA-AM $(10 \mu \mathrm{M})$ for $20 \mathrm{~min}$. However, the absence of extracellular $\mathrm{Ca}^{2+}\left(\left[\mathrm{Ca}^{2+}\right]_{\mathrm{o}}\right.$ free) did not affect GALP-induced increased migration. C, $\mathrm{B}_{1}$ agonist (Des- $\mathrm{Arg}^{9}$-BK)-induced microglial motility was inhibited by SN-6 (5 and $10 \mu \mathrm{M}$ ), a more specific inhibitor of reverse-mode NCX. D, On the other hand, GALP-induced microglial motility was not inhibited by SN-6. $* * \mathrm{P}<0.005, * * * p<0.001$.

constricted blood vessels [49]. This seems unlikely in the case of GAL. Furthermore, GAL up-regulated the expression of major histocompatibility complex (MHC) molecule class II (MHC-II) determined by antiMHC Class II antibody (OX-6) expression, while BK did not significantly induce MHC-II expression [14]. As for the mechanism leading to MHC-II gene expression, phosphoinositide 3-kinase (PI3K) and PKC might be required as was reported in IFN- $\gamma$-stimulated macrophages [67], while serine/threonine kinase activity, possibly MAPK, and tyrosine kinase activity, are required for IFN- $\gamma$-induced expression of MHC-II genes in astroglioma [68]. Though the precise signal cascade which leads to MHC-II expression from activation of GalR2 receptor has not yet been analyzed, it was suggested that GAL induces an immunological response, unlike BK.

Even though functional changes in microglia are differently induced by BK and GAL, both GAL and BK may be neuroprotective. Both GAL $(\sim 1 \mathrm{pM})$ and BK $(300 \mathrm{nM} \sim)$ inhibited LPS-induced TNF- $\alpha$ production in microglial cells $[25,61]$. It was reported that GAL acts as a neuroprotective factor to the hippocampus [69] and BK may also work as a neuroprotective agent through a negative-feedback mechanism on the LPSinduced inflammatory response [24, 49]. Therefore, the differences in down-stream signal transduction induced by GAL and BK suggest that GAL and BK may control distinct microglial functions under pathological conditions.

\section{DISTINCT MECHANISM LEADING TO MICROGLIAL MIGRATION BY ATP AND NEUROPEPTIDE}

As a conclusion, many substances released from pathologic sites work as chemoattractants for microglia, brain's immune cell population. The mechanisms leading to microglial migration and other functions, such as NO formation or adaptive immune response, may be distinct in each chemoattractant, e.g., ATP and neuropeptides such as BK and GAL. Figure 6 summarizes the different signaling induced by each chemoattractant. ATP binds to $\mathrm{P}_{2} \mathrm{Y}_{12}$ receptor which 


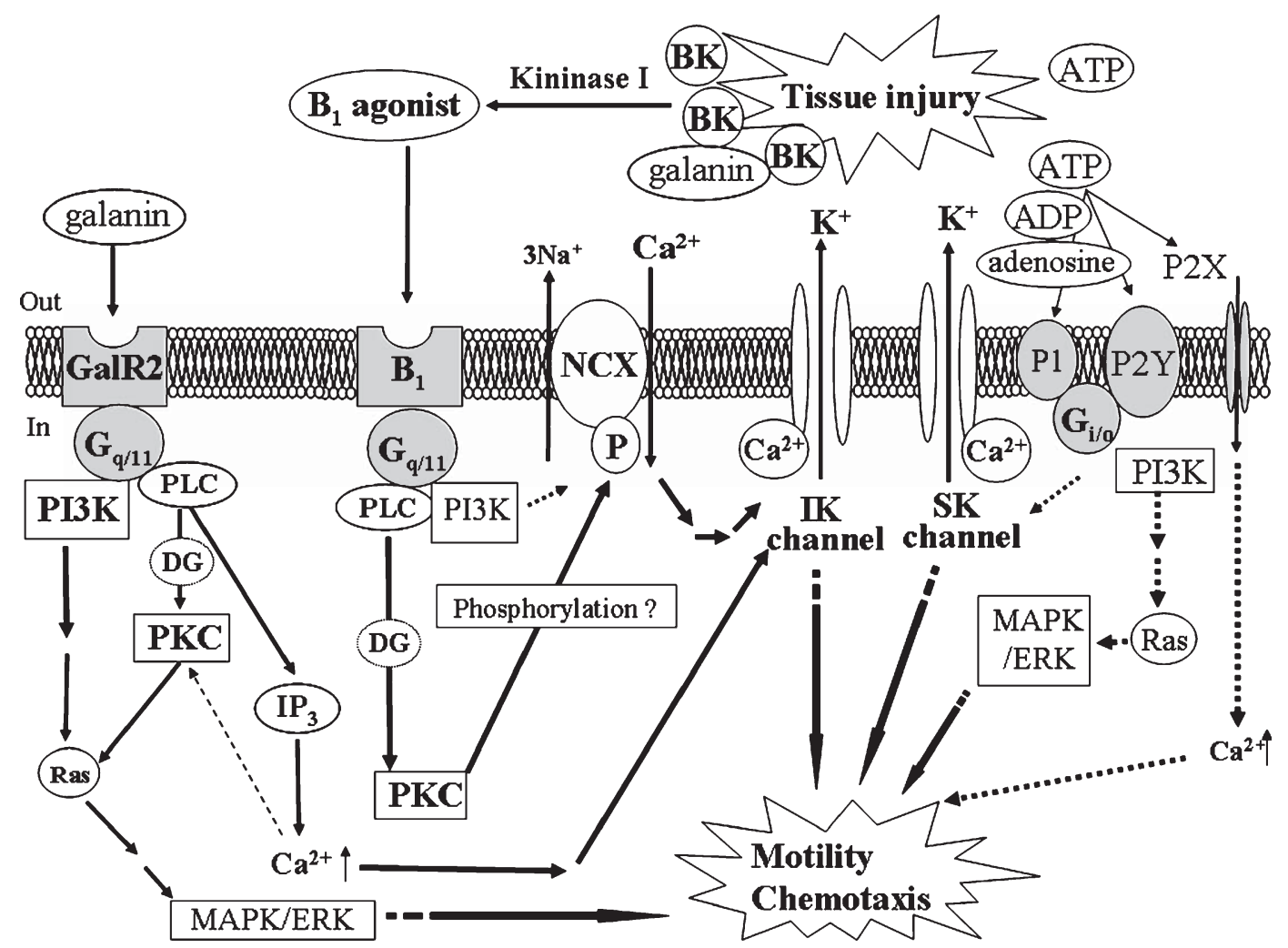

Fig. 6. ATP, BK and GAL activate different signaling cascades leading microglial migration. ATP binds to $P 2 Y_{12}$ receptor which couples to $\mathrm{G}_{\mathrm{i} / \mathrm{o}}$ protein-dependent signaling, leading activation of PI3K [6] and MAPK/ERK. Activation of P2X $\mathrm{X}_{4}$ also contributes to ATP-induced microglial migration [52], allowing influx of $\mathrm{Ca}^{2+}$ and activates SK-type $\mathrm{K}_{(\mathrm{Ca})}$ channel (Noda et al. , unpublished data). BK is metabolized to $\mathrm{B}_{1}$ agonist by kininase $I$ and activates $B_{1}$ receptor, coupling to $G_{q / 11}$ protein and activation of PLC and subsequent PKC. Though precise mechanism is unknown, the down stream cascade activates reverse mode of NCX, allowing influx of extracellular $\mathrm{Ca}^{2+}$, which activates IK-type of $\mathrm{K}_{(\mathrm{Ca})}$ channels. $\mathrm{B}_{1}$ agonist-induced microglial migration is also dependent on PI3K but not MAPK/ERK [14]. Another neuropeptides produced at lesion sites, GAL binds to GalR2 and also activates $\mathrm{G}_{\mathrm{q} / 11}$ protein-dependent pathway. However, GAL does not activate NCX but activates PKCand $\mathrm{IP}_{3}$-dependent pathway, leading to activation of $\mathrm{K}_{(\mathrm{Ca})}$ channels, presumably IK-type. GAL-induced microglial migration is also dependent on PI3K and MAPK/ERK [66].

couples to $\mathrm{G}_{\mathrm{i} / \mathrm{o}}$ protein-dependent signaling, via PI3K and MAPK/ERK, and also SK-type $\mathrm{K}_{(\mathrm{Ca})}$ channel activation. ATP binds to $\mathrm{P}_{2} \mathrm{X}_{4}$ receptors, contributing microglial migration by activating $\mathrm{K}_{(\mathrm{Ca})}$ channels.

To describe more precise mechanism induced by ATP, the effects of ATP on microglia are mediated through purinoceptors of both metabotropic and ionotropic subtypes [70]. This means that not only ATP but other purines (ADP, adenosine, etc.) can work at the same time. Microglia are endowed with ectonucleotidases, which degrade ATP and its derivatives. For example, microglial cells also express CD39 ectonucleotidase, which is critical for ATP-mediated signaling. In microglia deficient for CD39, migration cannot be stimulated by ATP [71]. The application of ATP in concert with adenosine or the addition of exogenous soluble ectonucleotidase, restored the ATP stimulated migration, thus indicating that both
$\mathrm{P} 1$ and $\mathrm{P} 2$ receptor stimulation are required and that the ectonucleotidases can provide the substrate for P1 receptors [71].

Different from of ATP-induced signaling, BK and GAL couple to $\mathrm{G}_{\mathrm{i} / \mathrm{o}}$-independent, presumably $\mathrm{G}_{\mathrm{q} / 11}$ protein, and activate PLC pathway. Despite the similarity in the signal cascades induced by $\mathrm{BK}$ and GAL, GAL-induced migration was not dependent on extracellular $\mathrm{Ca}^{2+}$, which was different from BK-induced migration [14]. According to pharmacological investigation, BK activates the pathway $\mathrm{PLC} \longrightarrow \mathrm{PKC} \longrightarrow$ reverse $\mathrm{NCX} \longrightarrow$ IK-type $\mathrm{K}_{(\mathrm{Ca})}$ channel. On the other hand, GAL activates the pathway $\mathrm{PLC} \longrightarrow-\mathrm{IP}_{3} \longrightarrow \mathrm{Ca}^{2+} \longrightarrow \mathrm{K}_{(\mathrm{Ca})}$ channel. It is not yet been known which type of $\mathrm{K}_{(\mathrm{Ca})}$ channel is involved in GAL-induced migration. PI3K is also involved in $\mathrm{BK}$ and GAL signaling, but MAPK/ERK signaling is involved only in GAL signaling (Fig. 6). 
So far, the signaling induced by ATP, BK and GAL has been investigated but many other chemoattractants would be also good candidates and may show further differences in signaling. Further research on these may help to understand the role of microglia and the potentially-important relationship between microglia and neuropeptides.

\section{ACKNOWLEDGMENTS}

We thank Prof. Hokfelt (Karolinska Institute, Sweden) and Prof. D.A. Brown (University College London, UK) for valuable suggestions. We also thank Prof. H. Kettenmann, Drs. K. Färber, and S. Seifert (Max-Delbrück Center for Molecular Medicine, Berlin, Germany) for experimental help and useful comments. This work was supported by Grantsin Aid for Scientific Research of Japan Society for Promotion of Science, Japan.

\section{REFERENCES}

[1] Kim SU, de Vellis J. Microglia in health and disease. J Neurosci Res. 2005; 81(3): 302.

[2] Kreutzberg GW. Microglia: a sensor for pathological events in the CNS. Trends Neurosci. 1996; 19(8): 312.

[3] Perry VH, Andersson PB, Gordon S. Macrophages and inflammation in the central nervous system. Trends Neurosci. 1993; 16(7): 268.

[4] Takano T, Han X, Deane R, Zlokovic B, Nedergaard M. Two-photon imaging of astrocytic $\mathrm{Ca}^{2+}$ signaling and the microvasculature in experimental mice models of Alzheimer's disease. Ann N Y Acad Sci. 2007; 1097: 40.

[5] Volterra A, Meldolesi J. Astrocytes, from brain glue to communication elements: the revolution continues. Nat Rev Neurosci. 2005; 6(8): 626.

[6] Honda S, Sasaki Y, Ohsawa K, Imai Y, Nakamura Y, Inoue K. et al. Extracellular ATP or ADP induce chemotaxis of cultured microglia through Gi/o-coupled P2Y receptors. J Neurosci. 2001; 21(6): 1975

[7] Davalos D, Grutzendler J, Yang G, Kim JV, Zuo Y, Jung S. et al. ATP mediates rapid microglial response to local brain injury in vivo. Nat Neurosci. 2005; 8(6): 752.

[8] Walter L, Franklin A, Witting A, Wade C, Xie Y, Kunos G. et al. Nonpsychotropic cannabinoid receptors regulate microglial cell migration. J Neurosci. 2003; 23(4): 1398.

[9] Takayama N, Ueda H. Morphine-induced chemotaxis and brain-derived neurotrophic factor expression in microglia. $\mathrm{J}$ Neurosci. 2005; 25(2): 430.

[10] Rappert A, Biber K, Nolte C, Lipp M, Schubel A, Lu B. et al. Secondary lymphoid tissue chemokine (CCL21) activates $\mathrm{CXCR} 3$ to trigger a $\mathrm{Cl}$ - current and chemotaxis in murine microglia. J Immunol. 2002; 168(7): 3221.

[11] Schilling T, Stock C, Schwab A, Eder C. Functional importance of $\mathrm{Ca}^{2+}$-activated $\mathrm{K}^{+}$channels for lysophosphatidic acid-induced microglial migration. Eur J Neurosci. 2004; 19(6): 1469.
[12] Liu GJ, Nagarajah R, Banati RB, Bennett MR. Glutamate induces directed chemotaxis of microglia. Eur J Neurosci. 2009; 29(6): 1108.

[13] Farber K, Pannasch U, Kettenmann H. Dopamine and noradrenaline control distinct functions in rodent microglial cells. Mol Cell Neurosci. 2005; 29(1): 128.

[14] Ifuku M, Farber K, Okuno Y, Yamakawa Y, Miyamoto T, Nolte C. et al. Bradykinin-induced microglial migration mediated by $\mathrm{B} 1$-bradykinin receptors depends on $\mathrm{Ca}^{2+}$ influx via reverse-mode activity of the $\mathrm{Na}^{+} / \mathrm{Ca}^{2+}$ exchanger. J Neurosci. 2007; 27(48): 13065.

[15] Schwab A. Function and spatial distribution of ion channels and transporters in cell migration. Am J Physiol Renal Physiol. 2001; 280(5): F739.

[16] Schwab A. Ion channels and transporters on the move. News Physiol Sci. 2001; 16: 29.

[17] Griebel G. Is there a future for neuropeptide receptor ligands in the treatment of anxiety disorders?. Pharmacol Ther. 1999; 82(1): 1.

[18] Holmes A, Heilig M, Rupniak NM, Steckler T, Griebel G. Neuropeptide systems as novel therapeutic targets for depression and anxiety disorders. Trends Pharmacol Sci. 2003; 24(11): 580.

[19] Hokfelt T, Broberger C, Xu ZQ, Sergeyev V, Ubink R, Diez M. Neuropeptides-an overview. Neuropharmacology. 2000; 39(8): 1337.

[20] Chao J, Chao L, Swain CC, Tsai J, Margolius HS. Tissue kallikrein in rat brain and pituitary: regional distribution and estrogen induction in the anterior pituitary. Endocrinology. 1987; 120(2): 475.

[21] Raidoo DM, Bhoola KD. Pathophysiology of the kallikreinkinin system in mammalian nervous tissue. Pharmacol Ther. 1998; 79(2): 105.

[22] Scicli AG, Forbes G, Nolly H, Dujovny M, Carretero OA. Kallikrein-kinins in the central nervous system. Clin Exp Hypertens A. 1984; 6(10-11): 1731 .

[23] Walker K, Perkins M, Dray A. Kinins and kinin receptors in the nervous system. Neurochem Int. 1995; 26(1): 1.

[24] Noda M, Kettenmann H, Wada K. Anti-inflammatory effects of kinins via microglia in the central nervous system. Biol Chem. 2006; 387(2): 167.

[25] Noda M, Kariura Y, Pannasch U, Nishikawa K, Wang L, Seike T. et al. Neuroprotective role of bradykinin because of the attenuation of pro-inflammatory cytokine release from activated microglia. J Neurochem. 2007; 101(2): 397.

[26] Yasuyoshi H, Kashii S, Zhang S, Nishida A, Yamauchi T, Honda Y. et al. Protective effect of bradykinin against glutamate neurotoxicity in cultured rat retinal neurons. Invest Ophthalmol Vis Sci. 2000; 41(8): 2273.

[27] Lehmberg J, Beck J, Baethmann A, Uhl E. Bradykinin antagonists reduce leukocyte-endothelium interactions after global cerebral ischemia. J Cereb Blood Flow Metab. 2003; 23(4): 441.

[28] Schulze-Topphoff U, Prat A, Prozorovski T, Siffrin V, Paterka M, Herz J. et al. Activation of kinin receptor B1 limits encephalitogenic $\mathrm{T}$ lymphocyte recruitment to the central nervous system. Nat Med. 2009; 15(7): 788.

[29] Noda M, Kariura Y, Amano T, Manago Y, Nishikawa K, Aoki S. et al. Expression and function of bradykinin receptors in microglia. Life Sci. 2003; 72(14): 1573.

[30] Stephens GJ, Cholewinski AJ, Wilkin GP, Djamgoz MB. Calcium-mobilizing and electrophysiological effects of bradykinin on cortical astrocyte subtypes in culture. Glia. 1993; 9(4): 269. 
[31] Gimpl G, Walz W, Ohlemeyer C, Kettenmann H. Bradykinin receptors in cultured astrocytes from neonatal rat brain are linked to physiological responses. Neurosci Lett. 1992; 144(1-2): 139 .

[32] Hosli L, Hosli E, Kaeser H, Lefkovits M. Colocalization of receptors for vasoactive peptides on astrocytes of cultured rat spinal cord and brain stem: electrophysiological effects of atrial and brain natriuretic peptide, neuropeptide $\mathrm{Y}$ and bradykinin. Neurosci Lett. 1992; 148(1-2): 114.

[33] Lin WW, Chuang DM. Regulation of bradykinin-induced phosphoinositide turnover in cultured cerebellar astrocytes: possible role of protein kinase C. Neurochem Int. 1992; 21(4): 573.

[34] Hsieh HL, Yen MH, Jou MJ, Yang CM. Intracellular signalings underlying bradykinin-induced matrix metalloproteinase- 9 expression in rat brain astrocyte-1. Cell Signal. 2004; 16(10): 1163.

[35] Hsieh HL, Wu CY, Hwang TL, Yen MH, Parker P, Yang CM. BK-induced cytosolic phospholipase A2 expression via sequential PKC-delta, p42/p44 MAPK, and NF-kappaB activation in rat brain astrocytes. J Cell Physiol. 2006; 206(1): 246.

[36] Hsieh HL, Wang HH, Wu CY, Jou MJ, Yen MH, Parker P. et al. BK-induced COX-2 expression via PKC-deltadependent activation of p42/p44 MAPK and NF-kappaB in astrocytes. Cell Signal. 2007; 19(2): 330.

[37] Schwaninger M, Sallmann S, Petersen N, Schneider A, Prinz $\mathrm{S}$, Libermann TA. et al. Bradykinin induces interleukin-6 expression in astrocytes through activation of nuclear factorkappaB. J Neurochem. 1999; 73(4): 1461.

[38] Liu HT, Akita T, Shimizu T, Sabirov RZ, Okada Y. Bradykinin-induced astrocyte-neuron signalling: glutamate release is mediated by ROS-activated volume-sensitive outwardly rectifying anion channels. J Physiol. 2009; 587(Pt 10): 2197.

[39] Fleisher-Berkovich S, Filipovich-Rimon T, Ben-Shmuel S, Hulsmann C, Kummer MP, Heneka MT. Distinct modulation of microglial amyloid beta phagocytosis and migration by neuropeptides (i). J Neuroinflammation. 2010; 7: 61

[40] Nimmerjahn A, Kirchhoff F, Helmchen F. Resting microglial cells are highly dynamic surveillants of brain parenchyma in vivo. Science. 2005; 308(5726): 1314.

[41] Fetler L, Amigorena S. Neuroscience. Brain under surveillance: the microglia patrol. Science. 2005; 309(5733): 392.

[42] Hanisch UK. Microglia as a source and target of cytokines. Glia. 2002; 40(2): 140.

[43] Liu Y, Shenouda D, Bilfinger TV, Stefano ML, Magazine HI, Stefano GB. Morphine stimulates nitric oxide release from invertebrate microglia. Brain Res. 1996; 722(1-2): 125.

[44] Saura J, Angulo E, Ejarque A, Casado V, Tusell JM, Moratalla R. et al. Adenosine A2A receptor stimulation potentiates nitric oxide release by activated microglia. J Neurochem. 2005; 95(4): 919.

[45] Stefano GB, Liu Y, Goligorsky MS. Cannabinoid receptors are coupled to nitric oxide release in invertebrate immunocytes, microglia, and human monocytes. J Biol Chem. 1996; 271(32): 19238.

[46] Moller T, Kann O, Verkhratsky A, Kettenmann H. Activation of mouse microglial cells affects $\mathrm{P} 2$ receptor signaling. Brain Res. 2000; 853(1): 49.

[47] Light AR, Wu Y, Hughen RW, Guthrie PB. Purinergic receptors activating rapid intracellular $\mathrm{Ca}$ increases in microglia. Neuron Glia Biol. 2006; 2(2): 125.

[48] Walz W, Ilschner S, Ohlemeyer C, Banati R, Kettenmann H. Extracellular ATP activates a cation conductance and a $\mathrm{K}^{+}$ conductance in cultured microglial cells from mouse brain. J Neurosci. 1993; 13(10): 4403.

[49] Noda M, Sasaki K, Ifuku M, Wada K. Multifunctional effects of bradykinin on glial cells in relation to potential antiinflammatory effects. Neurochem Int. 2007; 51(2-4): 185.

[50] Matsuda T, Arakawa N, Takuma K, Kishida Y, Kawasaki Y, Sakaue M. et al. SEA0400, a novel and selective inhibitor of the $\mathrm{Na}^{+}-\mathrm{Ca}^{2+}$ exchanger, attenuates reperfusion injury in the in vitro and in vivo cerebral ischemic models. J Pharmacol Exp Ther. 2001; 298(1): 249.

[51] Nagano T, Kawasaki Y, Baba A, Takemura M, Matsuda T. Up-regulation of $\mathrm{Na}^{+}-\mathrm{Ca}^{2+}$ exchange activity by interferongamma in cultured rat microglia. J Neurochem. 2004; 90(4): 784.

[52] Ohsawa K, Irino Y, Nakamura Y, Akazawa C, Inoue K, Kohsaka S. Involvement of P2X4 and P2Y12 receptors in ATP-induced microglial chemotaxis. Glia. 2007; 55(6): 604.

[53] Tatemoto K, Rokaeus A, Jornvall H, McDonald TJ, Mutt V. Galanin - a novel biologically active peptide from porcine intestine. FEBS Lett. 1983; 164(1): 124.

[54] Brecht S, Buschmann T, Grimm S, Zimmermann M, Herdegen $\mathrm{T}$. Persisting expression of galanin in axotomized mamillary and septal neurons of adult rats labeled for c-Jun and NADPH-diaphorase. Brain Res Mol Brain Res. 1997; 48(1): 7 .

[55] Cortes R, Villar MJ, Verhofstad A, Hokfelt T. Effects of central nervous system lesions on the expression of galanin: a comparative in situ hybridization and immunohistochemical study. Proc Natl Acad Sci U S A. 1990; 87(19): 7742.

[56] Hokfelt T, Wiesenfeld-Hallin Z, Villar M, Melander T. Increase of galanin-like immunoreactivity in rat dorsal root ganglion cells after peripheral axotomy. Neurosci Lett. 1987; 83(3): 217.

[57] Hokfelt T, Tatemoto K. Galanin-25 years with a multitalented neuropeptide. Cell Mol Life Sci. 2008; 65(12): 1793.

[58] Branchek TA, Smith KE, Gerald C, Walker MW. Galanin receptor subtypes. Trends Pharmacol Sci. 2000; 21(3): 109.

[59] Perez SE, Wynick D, Steiner RA, Mufson EJ. Distribution of galaninergic immunoreactivity in the brain of the mouse. $\mathrm{J}$ Comp Neurol. 2001; 434(2): 158.

[60] Gustafson EL, Smith KE, Durkin MM, Gerald C, Branchek TA. Distribution of a rat galanin receptor mRNA in rat brain. Neuroreport. 1996; 7(4): 953.

[61] Su Y, Ganea D, Peng X, Jonakait GM. Galanin down-regulates microglial tumor necrosis factor-alpha production by a posttranscriptional mechanism. J Neuroimmunol. 2003; 134(12): 52 .

[62] Habert-Ortoli E, Amiranoff B, Loquet I, Laburthe M, Mayaux JF. Molecular cloning of a functional human galanin receptor. Proc Natl Acad Sci U S A. 1994; 91(21): 9780.

[63] Smith KE, Walker MW, Artymyshyn R, Bard J, Borowsky B, Tamm JA. et al. Cloned human and rat galanin GALR3 receptors. Pharmacology and activation of G-protein inwardly rectifying $\mathrm{K}^{+}$channels. J Biol Chem. 1998; 273(36): 23321.

[64] Wang S, Hashemi T, Fried S, Clemmons AL, Hawes BE. Differential intracellular signaling of the GalR1 and GalR2 galanin receptor subtypes. Biochemistry. 1998; 37(19): 6711.

[65] Wittau N, Grosse R, Kalkbrenner F, Gohla A, Schultz G, Gudermann T. The galanin receptor type 2 initiates multiple signaling pathways in small cell lung cancer cells by coupling to $G(q), G(i)$ and $G(12)$ proteins. Oncogene. 2000; 19(37): 4199.

[66] Ifuku MOY, Yamakawa Y, Izumi K, Seifert S, Kettenmann H, Noda M. Functional importance of inositol-1,4,5triphosphate-induced intracellular $\mathrm{Ca}^{2+}$ mobilization in 
galanin-induced microglial migration. J Neurochem. 2011; 117(1): 61.

[67] Hardy PO, Diallo TO, Matte C, Descoteaux A. Roles of phosphatidylinositol 3-kinase and $\mathrm{p} 38$ mitogen-activated protein kinase in the regulation of protein kinase $\mathrm{C}$-alpha activation in interferon-gamma-stimulated macrophages. Immunology. 2009; 128(1 Suppl): e652.

[68] Van Wagoner NJ, O'Keefe GM, Benveniste EN. Kinase inhibitors abrogate IFN-gamma-induced class II transactivator and class II MHC gene expression in astroglioma cell lines. J Neuroimmunol. 1998; 85(2): 174.
[69] Elliott-Hunt CR, Marsh B, Bacon A, Pope R, Vanderplank $\mathrm{P}$, Wynick D. Galanin acts as a neuroprotective factor to the hippocampus. Proc Natl Acad Sci U S A. 2004; 101(14): 5105.

[70] Farber K, Kettenmann H. Purinergic signaling and microglia. Pflugers Arch. 2006; 452(5): 615.

[71] Farber K, Markworth S, Pannasch U, Nolte C, Prinz V, Kronenberg G. et al. The ectonucleotidase cd39/ENTPDase 1 modulates purinergic-mediated microglial migration. Glia. 2008; 56(3): 331 